\title{
EFFECT OF INTERACTION BETWEEN BIOFERTILIZERS AND SALINE IRRIGATION WATER ON THE PRODUCTIVITY OF SAFFLOWER (Carthamus tinctorius L) IN NORTHERN SINAI - EGYPT \\ El-Sayed, M. A. M. \\ Soil Fertility and Microbiology Department, Desert Research Center, El- Mataria, Cairo, Egyp mahalyeg@yahoo.com
}

\begin{abstract}
Two field experiments were carried out during the two successive seasons (2007/2008 and 2008/2009) at the experimental station of El Sheikh Zowayed, Desert Research Center to study the effect of biofertilizer application (Azotobacter chrococcum, Azospirillum lipoferum and mixture of them) under three levels of saline irrigation water $\left(2000,3000\right.$ and $\left.4000 \mathrm{\mu gl}^{-1}\right)$ on growth and productivity of safflower (Carthamus tinctorius L).

The obtained results showed that, biofertilizer treatments significantly increased microbial activities in safflower rhizosphere (total bacterial counts, azotobacters and azospirilla densities, $\mathrm{CO}_{2}$ evolution and dehydrogenase activity). Also, biofertilizers enhanced plant height, number of branches per plant, fresh and dry weight /plant. On the other hand, nitrogen content in soil and shoots plant at 35, 70 and 120 days from sowing increased by inoculation with biofertilizers during the two seasons. Number of heads /plant, head diameter, number of seeds /head, weight of 100 seed, stand, protein, phosphorus, oil content and oil yield at harvest significantly increased in biofertilizers treatments. Dual inoculation treatment gave the highest values of growth characters, yield and chemical composition of safflower plant as well as microbial activities in safflower rhizosphere.

Increasing salinity in irrigation water from 2000 to $4000 \mathrm{\mu gl}^{-1}$ significantly decreased microbial activities in safflower rhizosphere, growth characters, yield, yield components and chemical contents of plant.

Interaction between biofertilizer treatments and salinity had a significant effect on microbial activities in safflower rhizosphere. Also, application of dual or individual biofertilizer with saline irrigation water improved plant growth and yield and yield components of safflower compared with uninoculated plants.
\end{abstract}

Keywords: Safflower variety (Giza 1), biofertilizers, salinity, microbial counts, growth, yield, chemical composition.

\section{INTRODUCTION}

Safflower provides three principle products: oil, meal and birdseed. Safflower oil is used by both food producers and industry. Safflower oil consists of two types with corresponding types of safflower varieties: those high in monounsaturated fatty acid (oleic) and those high in polyunsaturated fatty acid (linoleic).

Soil and water salinity are a wide spread problem in crop production. However, this problem is usually confined to arid and semi-arid regions. Saline conditions cause physical and chemical changes in soil and significantly decrease the soil productivity. The type as well as the 
concentration of salts affect soil structure and interfere with the nutrition of plant. The anion of salt whether chloride or sulphate is also important. Several investigations concluded that increasing salinity decreased the yield components of safflower such as seed yield, biomass yield (dry weight), number of plant per hectare, 1000- seed weight, plant height, number of capitula per plant and capitula weight per plant, Mohammad et al. (2010).

Several investigations concluded that increasing salinity decreased the vegetatative growth characteristics and yield of safflower plants. Rumasz et al. (2002) and Muhammad et al. (2007) found that increasing salt concentration from 0 to $150 \mathrm{~mm} \mathrm{NaCl}$, significantly decreased dry root and shoot weight, fresh leaf weight and leaf area of Beta vulgaris $L$.

Biofertilizer is a natural organic fertilizer known that helps to provide all the nutrients required by the plants and helps to supply and increase the soil with natural and beneficial microorganism. Biofertilizers are the most advanced biotechnology necessary to support developing organic agriculture, sustaintable agriculture, green agriculture and safe agriculture. Mixed bacterial inoculation increased growth and yield of different plant species as compared with uninoculation. This was shown by (Rahim and Mirzaei, 2010.) who found that significant increase was observed on yield and yield component of safflower with applying biofertilizers. Also applying Azotobacter and Azospirillum increased seed yield and yield components by 35 and $21 \%$ respectively compared with control.

The aim of this study is to evaluate the role of biofertilizers under different levels of irrigation water salinity on the microbial activities. as well as the growth and productivity of safflower at North Sinai, Egypt.

\section{MATERIALS AND METHODS}

Determination of nitrogen fixing capacity by Azotobacter spp. And Azospirillum spp. in pure culture: Fixed Nitrogen in cultures media was determined after 7 days from incubation as mentioned by Bremner, (1965). Briefly, Azotobacter spp. and Azospirillum spp. isolates were grown in $10 \mathrm{ml}$ Ashby medium or Dobereiner medium (without agar) in $20 \mathrm{ml}$ test tube on a rotary shaker $(125 \mathrm{rpm})$ under continuous airflow at $30^{\circ} \mathrm{C}$ for $72 \mathrm{hr}$. Cell

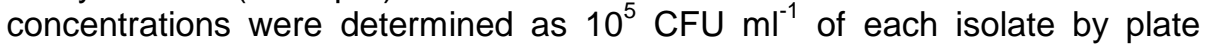
counts on agar Ashby or Dobereiner medium. The non-inoculated media served as control. Afterwards, the concentration of nitrogen in each liquid culture was measured by digestion and subsequent measurement by the Kjeldahl method (Bremner, 1965). The quantities of nitrogen reported represent the average of duplicate cultures after deducting the average of duplicate controls.

Two field experiments were carried out on safflower plant (Carthamus tinctorius L) at El- Sheikh Zowayed Research Station, Desert Research Center, North Sinai Governorate, Egypt, during two successive growing seasons (2007/2008 and 2008/2009). 
Mechanical and chemical analysis of the experimental soil were carried out according to Richards (1954); Black (1965) and Jackson (1967) as shown in Table (1).

Each experiment included twelve treatments which were the combintation of three salinity levels of irrigation water $\left(2000 \mathrm{gl}^{-1}, 3000 \mathrm{\mu gl}^{-1}\right.$, and $\left.4000 \mathrm{\mu gl}^{-1}\right)$ and three biofertilizer treatments (Azotobacter chrococcum, Azospirillum lipoferum and their mixture) in addition to controls (without bacterial inoculation).

\section{Bacterial culture preparation.}

The fresh liquid cultures were prepared from pure local strains of Azotobacter chrococcum and Azospirillum lipoferum which previously isolated in Bunt and Rovira medium and semi solid malate medium from the rhizosphere of safflower plant grown in El Sheikh Zowayed area, respectively. They were purified and identified according to Bergey Manual (1984). Biofertilizers were added in the form of individual and mixed inoculations at the rate of $\sim 10^{8} \mathrm{cfu} / \mathrm{ml}$ as soil treatment. Safflower seeds were treated before planting with individual or mixture of bacterial suspensions for three hours before transplanting (carboxy methyl cellulose $0.5 \%$ was used as an adhesive agent). Seed without microbial treatment was served as control.

The design of experiment was split plot with three replication, each split included 12 treatments which were the combination between three levels of saline irrigation water $\left(2000,3000\right.$ and $\left.4000 \mathrm{\mu gl}^{-1}\right)$ and four biofertilizer treatments. The main plots were devoted to saline irrigation water levels, while the sub-plots were occupied by the biofertilizer. The experimental plot area was $10.5 \mathrm{~m}^{2}(3 / \mathrm{m} \times 3.5 \mathrm{~m})$, consisting of 6 ridges, each of $50 \mathrm{~cm}$ width and $3.5 \mathrm{~m}$ length, $50 \mathrm{~cm}$ were between hills and four seeds were sown in each hill. Before sowing, sheep manure $\left(15 \mathrm{~m}^{3}\right.$ fed.) was mixed with the upper soil. $150 \mathrm{~kg}$ calcium super phosphate $/ \mathrm{fed}$. $\left(15.5 \% \mathrm{P}_{2} \mathrm{O}_{5}\right)$ were added during seed-bed preparation before sowing and mixed with the surface layer. In addition, $150 \mathrm{~kg}$ ammonium sulphate / fed. $(20.5 \% \mathrm{~N})$ and $100 \mathrm{~kg}$ potassium sulphate / fed. $\left(48 \% \mathrm{~K}_{2} \mathrm{O}\right)$ were applied in two equal portions; after 15 and 21 days from sowing.

Safflower seeds (Giza1variety) were sown on $15^{\text {th }}$ October in the two growing seasons; the plants were thinned to one plant per hill after fifteen days from sowing. The experiment was irrigated immediately after sowing by water pumped from a well $\left(2000 \mathrm{\mu gl}^{-1}\right)$. The analysis of irrigation water is given in Table (2). Chemical analysis of sheep manure is given in Table (3).

Table (1): Physical and Chemical analyses of soil experimental station

\begin{tabular}{|c|c|c|c|c|c|c|c|c|c|c|c|c|c|c|}
\hline \multirow{3}{*}{ 咅 } & \multicolumn{5}{|c|}{ Physical properties } & \multicolumn{9}{|c|}{ Chemical properties } \\
\hline & \multirow{2}{*}{ 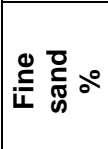 } & \multirow{2}{*}{ 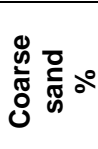 } & \multirow{2}{*}{ ら } & \multirow{2}{*}{$\frac{\vec{\pi}}{0} \circ$} & \multirow{2}{*}{ 咅 } & \multirow{2}{*}{$\frac{I}{2}$} & \multirow{2}{*}{ 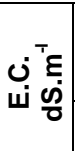 } & \multicolumn{2}{|c|}{\begin{tabular}{|c|} 
Soluble \\
anions(meq./L. \\
)
\end{tabular}} & \multicolumn{4}{|c|}{$\begin{array}{l}\text { Soluble cations } \\
\text { (meq. /L.) }\end{array}$} & \multirow{2}{*}{$\begin{array}{l}\text { ○̊ } \\
\text { రొ } \\
\text { ర }\end{array}$} \\
\hline & & & & & & & & $\mathrm{HCO}^{-}$ & $\mathrm{Cl}^{-} \mathrm{SO} 4=$ & $\mathrm{Ca}^{++}$ & $\mathrm{Mg}^{++}$ & $\mathrm{Na}^{+}$ & $\mathrm{K}^{+}$ & \\
\hline $0-30$ & 98.50 & 0.30 & \begin{tabular}{|l|}
0.69 \\
\end{tabular} & 0.51 & Sandy & 7.81 & \begin{tabular}{|l|}
0.31 \\
\end{tabular} & 0.87 & \begin{tabular}{|l|l|}
1.05 & 1.20 \\
\end{tabular} & 1.04 & 0.35 & 1.56 & 0.17 & 1.45 \\
\hline
\end{tabular}


El-Sayed, M. A. M.

Table (2): Chemical analysis of irrigation water of the Station

\begin{tabular}{|c|c|c|c|c|c|c|c|c|c|c|}
\hline $\begin{array}{c}\text { Irrigation } \\
\text { water } \\
\text { types }\end{array}$ & $\mathbf{P H}$ & \multirow{2}{*}{$\begin{array}{c}\text { E.C. } \\
\mathbf{d S}^{-1} \mathbf{m}^{-1}\end{array}$} & \multicolumn{2}{|c|}{ Soluble cations, meq. /L } & \multicolumn{3}{|c|}{ Soluble anions, meq. /L } \\
\hline $\mathbf{2 0 0 0}$ & 7.7 & 3.13 & 2.2 & 2.8 & 26 & 0.34 & 0 & 2.3 & 3.34 & 25.7 \\
\hline $\mathbf{3 0 0 0}$ & 7.86 & 4.69 & 4.6 & 5.4 & 36 & 0.89 & 0 & 2.7 & 5.2 & 39 \\
\hline $\mathbf{4 0 0 0}$ & 7.91 & 6.25 & 8.5 & 9.7 & 43.4 & 0.9 & 0 & 3.4 & 9.9 & 49.2 \\
\hline
\end{tabular}

Table (3): Chemical analysis of sheep manure.

\begin{tabular}{|l|c|l|c|}
\hline \multicolumn{1}{|c|}{ Type of analysis } & \multicolumn{1}{|c|}{ Type of analysis } & \\
\hline $\mathrm{PH}$ & 7.91 & Soluble ions (meq I) & \\
\hline Organic matter \% & 59.83 & Phosphorus (P) & 4.2 \\
\hline Organic carbon \% & 34.78 & Potassium (K) & 13.8 \\
\hline Total elements (\%) & & Calcium (Ca) & 8.3 \\
\hline Nitrogen & 2.31 & Magnesium (Mg) & 6.5 \\
\hline Phosphorus & 0.51 & Sodium (Na) & 25.6 \\
\hline Potassium & 1.01 & SD kg /m3 & 466 \\
\hline Calcium & 4.32 & & \\
\hline Magnesium & 0.26 & & \\
\hline C /N ratio & 15.06 & & \\
\hline EC in dS $/ \mathrm{m}^{-1}(1: 10)$ & 5.79 & & \\
\hline
\end{tabular}

\section{Determinations}

Samples of rhizosphere and plants were taken after 35, 70 and 120 days from sowing to determine microbial activities, growth characters, chemical composition and yield and yield components.

\section{A- Microbial determination:-}

Total bacterial, Azotobacter chrococcum and Azospirillum lipoferum conts in the rhizosphere samples were counted on Bunt and Rovira medium (Bunt and Rovira, 1955), nitrogen deficient medium (Abd El Malek and Ishac, 1968) and semi solid malate medium (Dobereiner, 1978), respectively. Also, $\mathrm{CO}_{2}$ evolution ( $\mu \mathrm{g} / \mathrm{g}$ dry soil/ $\mathrm{hr}$.) and dehydrogenase activity ( $\mu \mathrm{g}$ TPF $\mathrm{g}-{ }^{1}$. dry soil 24h.) in the rhizosphere were determined according to Pramer and Schmidt (1964) and Thalmann (1967), respectively.

\section{B- Growth characters:}

Three guarded plants were randomly taken from the three inner ridges of each experimental plot to measure plant height $(\mathrm{cm})$, number of branches/plant, fresh weight / plant (g) and dray weight / plant (g).

\section{C- Yield and its components:}

Three inner ridges of each experimental plot were taken to measured number of heads/ plant, head diameter $(\mathrm{cm})$, number of seeds / head, weight of 100 seeds $(\mathrm{g})$, stand $\%$ and seed yield $(\mathrm{Kg} / \mathrm{fed}$.).

\section{D- Chemical composition:}

Chemical composition was determined in seeds after 120 days from sowing date as following.

1- Protein content: total nitrogen percentage was determined by using the modified microkjeldahl method as described by Peach and Tracey (1956). The protein content was calculated by multiplying the total nitrogen by 6.25 Tripath et al. (1971). 
2- Phosphorus percentage was determined by ascorbic acid according to method reported by Frie et al. (1964).

3- Oil percentage was determined according to the method described in the official and tentative methods of American Oil Chemists (A.O.C.S. 1964).

4- Oil yield ( $\mathrm{kg} / \mathrm{fed}$.) was calculated by multiplying seed yield $\mathrm{Kg} / \mathrm{fed}$ by seed oil percentage.

Nitrogen content in soil samples and total nitrogen in shoots of plant were determined at 35,70 and 120 days from sowing.

\section{Statistical analysis:}

All the obtained data were subjected to the proper statistical analysis of variance according to the procedure outlined by Snedecor and Cochran (1989). Mean values of treatments were differentiated by using L.S.D at $5 \%$ level as mentioned by Steel (1960).

\section{RESULTS AND DISCUSSION}

\section{Fixed nitrogen in cultures media}

This laboratorial experiment was conducted on microbial strains (i.e., Azotobacter, Azospirillum and mixture of them) to evaluate the direct effect of irrigation water salinity, (i.e., 2000, 3000 and $4000 \mathrm{ppm}$ ) on the ability of these microbial strains for $\mathrm{N}$-fixation and compare their ability in soil which contain either beneficial or harmful microorganisms in addition to the presence of elements of fertilizers which may have a negative or positive effect on microbial activity.

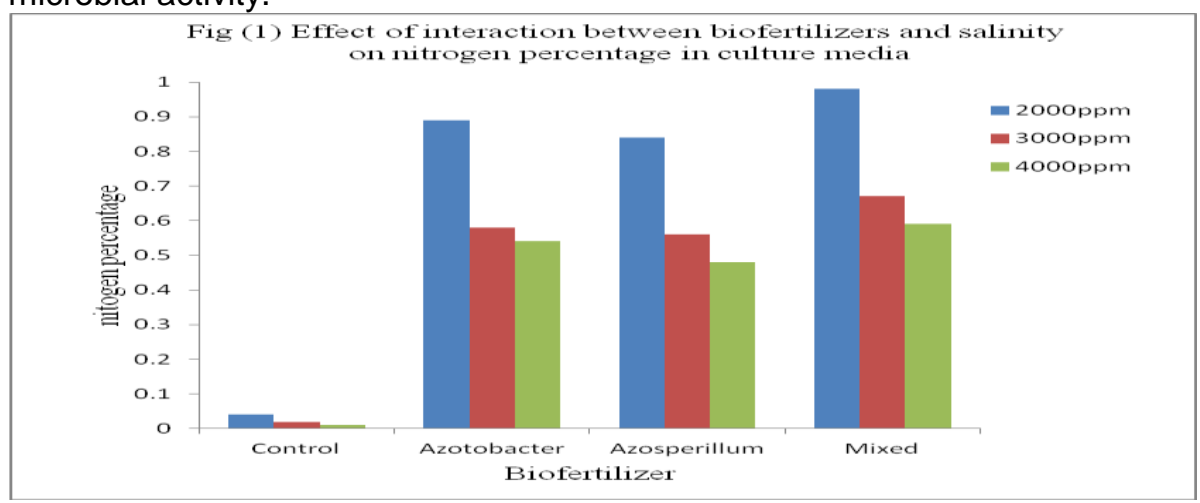

Figure (1) showed that the $\mathrm{N}$-fixation under salinity level of $2000 \mathrm{ppm}$ was high for all three treatments (i.e., Azotobacter, Azospirillum and mixture of them). While the $\mathrm{N}$-fixation at $3000 \mathrm{ppm}$ reduced by 35,33 and $31 \%$, respectively and the rate of reduction at $4000 \mathrm{ppm}$ were 39,43 and $34 \%$, respectively. This shows that the activity of Azotobacter was higher in Nfixation at the three levels of salinity of irrigation water comparing to the activity of Azospirillum under the same levels that mentioned above. These results agreed with Faid, (2000) and EL-Tayeb (2000). 
Interaction effect of biofertilizers and saline irrigation water on microbial activities in safflower rhizosphere:

1-Total microbial counts:

Data illustrated in Table (4) showed that increased salinity of irrigation water from $2000 \mathrm{mgl}^{-1}$ to $4000 \mathrm{mgl}^{-1}$ decreased total microbial counts of safflower rhizosphere at 35, 70 and 120 days from sowing in the two seasons. Co-inoculation with Azotobacter and Azospirillum gave the highest total microbial counts as compared with the others treatments in the two seasons. The positive response of growth as a result of Co-inoculation may be due to the fact that Azotobacter is free-living, nitrogen-fixing bacteria and is known to produce several plant growth promoting subustances. Abd ElGhany (1996) and Abd El-Gawad (2008), confirmed these results that microbial inoculates improve fertility, increase the number and biological activities of desired microorganisms in root environment.

Data also show that increasing salinity from $2000 \mu \mathrm{gl}^{-1}$ to $4000 \mu \mathrm{gl}^{-1}$ caused a significant decrease in total microbial counts after 35,70 and 120 days from sowing in the two seasons. The interaction between saline irrigation water and biofertilizer was significant at 35 days from sowing in the two seasons. The highest counts of all bacteria under study was after 70 days from sowing under all levels of saline irrigation water.

\section{2- Azotobacter chrococcum densities:}

Data in Table (4) also showed that the highest count of Azotobacter was at 70 days from sowing in the two successive seasons compared with the other periods. Increasing salinity of irrigation water from $2000 \mu \mathrm{gl}^{-1}$ to 4000 $\mathrm{\mu gl}^{-1}$ significantly decreased Azotobacter count at the three periods of plant growth i.e. 35, 70 and 120 days from sowing in the two seasons. The data are agreement with those recorded by (Hashem and Abd El-Ghany, 1992). The highest count of Azotobacter was obtained from the mixture of Azotobacter and Azospirillum in the two seasons.

\section{3- Azospirilla densities:}

Results in Table (5) reveal that biofertilizer treatments significantly affected azospirilla densities. The highest value of azospirilla densities was obtained by mixture inoculation with Azotobacter and Azospirillum at all sampling dates in two seasons. These data are in agreement with those recorded by Abd El-Gawad (2008).

Results in Table (5) indicate that increasing salinity in irrigation water up to $4000 \mathrm{\mu gl}^{-1}$ significantly decreased azospirilla densities after 35,70 and 120 days from sowing in the two seasons compared with $2000 \mathrm{\mu gl}^{-1}$.

Growing plants at high level of salinity $\left(4000 \mathrm{mgl}^{-1}\right)$ reduced azospirilla densities as compared to those irrigated by $2000{\mu \mathrm{gl}^{-1}}^{-1}$ by $49.23,63.21$ and $42.98 \%$ at 35,70 and 120 days respectively, in the first season and by $45.78,50.90$ and $63.92 \%$ at 35,70 and 120 days respectively, in the second season.

\section{4- $\mathrm{CO}_{2}$ evolution:}

The results shown in the Table (5) indicate that the rate of $\mathrm{CO}_{2}$ evolution as a criterion for biological activity in the safflower rhizosphere gave the highest levels with mixed treatments of biofertilizer, followed by individual inoculation with $A$. chroococcum then Azospirllum lipoferum. The 
development of high biological activity was observed when water salinity ranged between 2000 and $3000 \mathrm{ggl}^{-1}$ while activity decreased at $4000 \mathrm{\mu gl}^{-1}$. Data of $\mathrm{CO}_{2}$ evolution were almost in harmony with those of total microbial counts discussed before. These results agreed with that of El-Sayed (2006).

Table (4): Effect of interaction between biofertilization and saline irrigation on total bacterial counts and Azotobacter densities during 2007/2008 and 2008/2009 seasons.

\begin{tabular}{|c|c|c|c|c|c|c|c|c|c|c|c|c|c|}
\hline & \multirow{2}{*}{\multicolumn{6}{|c|}{$\begin{array}{c}\text { Total bacterial counts } \\
\text { (Counts } \times 10^{5} \mathrm{CFU} / \mathrm{g} \text { dry soil) }\end{array}$}} & \multirow{2}{*}{\multicolumn{6}{|c|}{$\begin{array}{c}\text { Azotobacter densities } \\
\text { (Counts } \times 10^{4} \text { CFU g dry soil) }\end{array}$}} \\
\hline & & & & & & & & & & & & & \\
\hline & & \multicolumn{3}{|c|}{ Season 1} & \multicolumn{3}{|c|}{ Season 2} & \multicolumn{3}{|c|}{ Season 1} & \multicolumn{3}{|c|}{ Season 2} \\
\hline & & 35 & 70 & 120 & 35 & 70 & 120 & 35 & 70 & 120 & 35 & 70 & 120 \\
\hline \multirow{4}{*}{$\begin{array}{l}2000 \\
\mu g^{-1}\end{array}$} & Control & 11.5 & 14.1 & 13.9 & 14.1 & 16.8 & 12.2 & 14.6 & 18.0 & 14.5 & 12.1 & 18.0 & 14.3 \\
\hline & Azotoba & 22.4 & 27.7 & 24.8 & 24.8 & 31.5 & 25.9 & 25.5 & 28.1 & \begin{tabular}{|l|}
26.3 \\
\end{tabular} & 25.3 & 36.4 & 31.2 \\
\hline & Azospirllum & 20.6 & 24.4 & 22.9 & 23.9 & 28.7 & 23.8 & 24.0 & 27.3 & 25.3 & 23.7 & 32.1 & 28.6 \\
\hline & $\overline{\mathbf{M i}}$ & 24.4 & 28.6 & 26.8 & 26.7 & 31.5 & 27.2 & 30.3 & 36.4 & 34.4 & 31.2 & 45.3 & 38.6 \\
\hline \multirow{4}{*}{$\begin{array}{l}3000 \\
\mu g^{-1}\end{array}$} & Control & 11.8 & 12.2 & 12.2 & 8.7 & 12.6 & 13.1 & 11.5 & 16.3 & 13.1 & 12.6 & 17.6 & \begin{tabular}{|l|}
12.3 \\
\end{tabular} \\
\hline & Azotobacter & 20.1 & 25.9 & 23.8 & 20.4 & 27.7 & 24.6 & 22.4 & 27.3 & 25.8 & 23.7 & 32.2 & 28.6 \\
\hline & Azospirllum & 18.1 & 22.9 & 21.2 & 19.6 & 25.6 & 23.3 & 21.3 & 26.2 & 23.5 & 23.0 & 29.4 & 24.5 \\
\hline & Mixed & 22.9 & 26.4 & 25.9 & 22.4 & 28.6 & 26.7 & 26.6 & 35.4 & 32.6 & 28.1 & 43.0 & 37.0 \\
\hline \multirow{4}{*}{$\begin{array}{l}4000 \\
\mu g^{-1}\end{array}$} & Control & 8.1 & 9.8 & \begin{tabular}{|l|}
10.7 \\
\end{tabular} & 6.4 & 11.8 & 11.6 & 10.4 & 14.7 & $\mid 12.5$ & 10.9 & 15.0 & 12.3 \\
\hline & Azotobacter & 18.6 & 21 & 21.3 & 16.7 & 26.9 & 23.3 & 20.0 & 25.6 & 23.7 & 21.3 & 28.1 & 24.3 \\
\hline & Azospirllum & 16.0 & 19.1 & 18.7 & 15.6 & 23.8 & 21.0 & 18.6 & 24.8 & 21.0 & 21.2 & 27.2 & 23.5 \\
\hline & Mixed & 19.9 & 22.8 & 22.3 & 20 & 26.7 & 24.3 & 24.3 & 33.2 & 28.1 & 25.7 & 38.6 & 34.4 \\
\hline \multicolumn{14}{|c|}{ L.S.D. at $5 \%$ for } \\
\hline & Salin & 0.06 & 1.83 & 3.38 & 0.04 & 0.19 & 0.80 & 0.19 & 1.08 & 2.36 & 1.48 & 3.73 & 0.19 \\
\hline & Bio & 0.05 & 1.51 & 2.87 & 0.03 & 0.17 & 0.98 & 0.17 & 4.45 & 0.57 & 0.17 & 2.26 & 0.23 \\
\hline & Interaction & 0.09 & N.S & N.S & 0.06 & 0.27 & N.S & 0.29 & \begin{tabular}{|l|l|}
2.44 \\
\end{tabular} & 0.99 & 0.29 & 3.91 & 0.41 \\
\hline
\end{tabular}

Initial Azotobacter densities $30 \times 10^{2}$ cfu/gm dry soil

Table (5): Effect of interaction between biofertilization and saline irrigation on azospirilla densities and $\mathrm{CO}_{2}$ evoluted during $2007 / 2008$ and $2008 / 2009$ seasons.

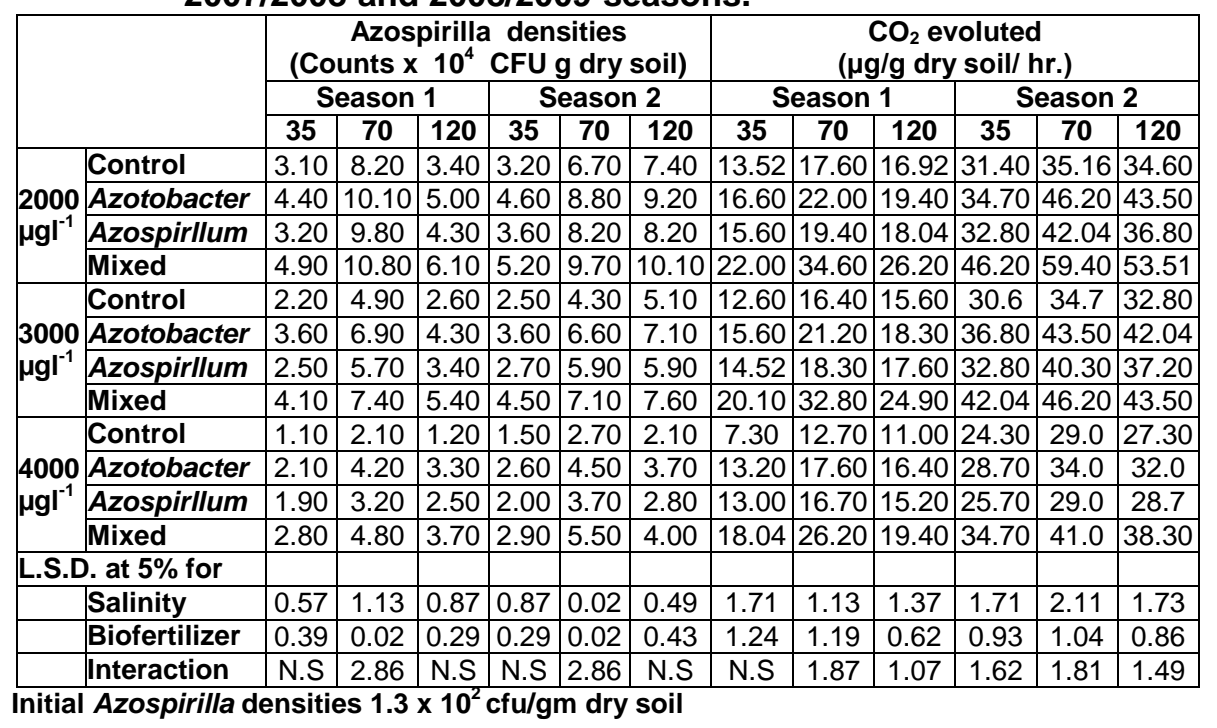




\section{5- Dehydrogenase activity:}

Dehydrogenase activity was determined as a criterion of respiration rate and total microbial activity in the safflower plant under different investigated treatments. Data presented in Table (6) showed that inoculated soil with individual or mixed inoculants significantly gave higher values of dehydrogenase activity when compared with uninoculated soil. In addition, mixed inoculation with $A$. chroococcum and Azospirillum sp. gave a significant higher dehydrogenase activity than the soil inoculated with each one individually. In addition, dehydrogenase activity exhibited its dominant increase at 70 days after sowing during both seasons with different treatments. Data also revealed that the level of salinity of irrigation water used had a major impact in dehydrogenase activity reaching the highest activity at 2000 and $3000 \mathrm{\mu gl}^{-1}$ when it went down at $4000 \mathrm{\mu gl}^{-1}$. In addition, dehydrogenase activity in various treatments were higher after 70 days. This may due to the difference in multiplication rate of different soil microorganisms which usually be maximum during flowering stage. Such differences could be attributed to the qualitative and quantitative changes in the nature of root exudates during different growth stages. These results are in harmony with Abd El-Gawad (1998) and Khalifa (2005).

Table (6): Effect of interaction between biofertilization and saline irrigation on dehydrogenase activity during 2007/2008 and 2008/2009 seasons.

\begin{tabular}{|c|c|c|c|c|c|c|c|}
\hline \multirow{4}{*}{ Salinity } & \multirow{4}{*}{ Inoculation } & \multicolumn{6}{|c|}{ Dehydrogenase activity ( $\mu \mathrm{g}$ TPF $\mathrm{g}^{-1}$. dry soil $24 \mathrm{~h}$. ) } \\
\hline & & \multirow{2}{*}{\multicolumn{3}{|c|}{$\begin{array}{c}\text { First season } \\
\text { Days after sowing }\end{array}$}} & \multirow{2}{*}{\multicolumn{3}{|c|}{$\begin{array}{l}\text { Second season } \\
\text { Days after sowing }\end{array}$}} \\
\hline & & & & & & & \\
\hline & & 35 & 70 & 35 & 70 & 35 & 70 \\
\hline \multirow{4}{*}{$\begin{array}{l}2000 \\
\mu \mathrm{gl}^{-1}\end{array}$} & Control & 4.95 & 6.88 & 5.22 & 5.81 & 6.96 & 6.12 \\
\hline & Azotobacter & 6.11 & 8.91 & 7.69 & 7.55 & 8.95 & 8.16 \\
\hline & Azospirllum & 5.05 & 7.85 & 7.05 & 6.36 & 7.81 & 7.25 \\
\hline & Mixed & 6.21 & 9.71 & 8.22 & 7.94 & 9.90 & 8.51 \\
\hline \multirow{4}{*}{$\begin{array}{l}3000 \\
\mu g^{-1}\end{array}$} & Control & 3.85 & 5.95 & 4.65 & 3.65 & 5.24 & 4.25 \\
\hline & Azotobacter & 5.41 & 7.52 & 6.56 & 5.50 & 7.05 & 6.14 \\
\hline & Azospirllum & 4.61 & 6.55 & 6.04 & 4.49 & 6.45 & 5.83 \\
\hline & Mixed & 5.33 & 8.61 & 7.68 & 6.15 & 8.21 & 7.07 \\
\hline \multirow{4}{*}{$\begin{array}{l}4000 \\
\mu \mathrm{gl}^{-1}\end{array}$} & Control & 2.59 & 3.72 & 3.52 & 2.37 & 4.09 & 3.21 \\
\hline & Azotobacter & 4.75 & 6.09 & 5.15 & 4.38 & 6.50 & 5.69 \\
\hline & Azospirllum & 4.14 & 5.79 & 4.86 & 3.42 & 5.37 & 4.59 \\
\hline & Mixed & 5.15 & 7.39 & 6.22 & 5.16 & 6.95 & 6.12 \\
\hline \multicolumn{8}{|c|}{ L.S.D. at $5 \%$ for } \\
\hline & Salinity & 0.85 & 0.57 & 0.57 & 0.54 & 0.83 & 0.68 \\
\hline & Biofertilizer & 0.85 & 0.95 & 0.86 & 0.55 & 0.89 & 0.56 \\
\hline & Interaction & N.S & N.S & N.S & N.S & N.S & N.S \\
\hline
\end{tabular}

*- Initial DHA $0.70 \mu \mathrm{g}$ TPF $\mathrm{g}^{-1}$. dry soil $24 \mathrm{~h}$.

\section{Nitrogen content in rhizosphere and shoots of safflower plant}

Data presented in Table (7) indicated that biofertilizer treatments significantly increased the content of nitrogen in rhizosphere and in shoots of safflower compared with uninoculated plants. Increasing salinity up to 4000 
$\mu \mathrm{gl}^{-1}$ had a significant decrease of nitrogen percentage in soil and in shoots of the plant either with biofertilizer application or without inoculation. Inoculation with mixture of $A$. chroococcum and Azospirllum lipoferum under $2000 \mu \mathrm{gl}^{-1}$ gave the highest values of nitrogen content in soil and in shoots at all sampling date during the two seasons. This result is compatible with the finding of EL-Tayeb (2000) who found that inoculation with selected halo tolerant Azospirllum strains resulted in considerable increases of growth and yield of wheat plants grown under the saline conditions of Egyptian desert soil.

Interaction between biofertilizers and water irrigation salinity on growth characters of safflower

The results summarized in Tables ( 8 and 9) revealed that biofertilizer treatments significantly affected on plant height, number of branches per plant, fresh and dry weight / plant after 35, 70 and 120 days from sowing during the two seasons. The highest value of growth characters and survival plant (stand \%) were obtained when plant were inoculated with mixture of Azotobacter and Azospirillum. In addition to nitrogen fixation by these bacteria, they are also known to protect plants against pathogenic microorganisims either by discouraging their growth or by destroying them. These inoculants need more attention in view of their triple action of nitrogen fixation, bio-control, and production of plant growth regulators. The positive response of growth to inoculation with Azospirillum and Azotobacter was described by several investigators including Mahmoud et al. (2012) and Paritosh et al. (2013).

Table (7): Effect of interaction between biofertilization and saline irrigation on nitrogen percentage in (soil samples and shoots of plant).

\begin{tabular}{|c|c|c|c|c|c|c|c|}
\hline \multirow{4}{*}{$\begin{array}{c}\text { Levels } \\
\text { Of } \\
\text { salinity } \\
\left(\mu \mathrm{gl}^{-1}\right)\end{array}$} & \multirow{4}{*}{ Inoculation } & \multicolumn{6}{|c|}{ Nitrogen (\%) } \\
\hline & & \multicolumn{3}{|c|}{ Soil } & \multicolumn{3}{|c|}{ Plant } \\
\hline & & \multicolumn{6}{|c|}{ Days after sowing } \\
\hline & & 35 & 70 & 120 & 35 & 70 & 120 \\
\hline \multirow{4}{*}{2000} & Control & 0.06 & 0.07 & 0.07 & 1.643 & 2.120 & 2.290 \\
\hline & Azotobacter & 0.16 & 0.19 & 0.18 & 2.707 & 3.100 & 3.260 \\
\hline & Azospirllum & 0.15 & 0.18 & 0.16 & 2.663 & 2.940 & 3.010 \\
\hline & Mixed & 0.18 & 0.21 & 0.19 & 2.827 & 3.260 & 3.343 \\
\hline \multirow{4}{*}{3000} & Control & 0.05 & 0.07 & 0.05 & 1.323 & 2.007 & 2.127 \\
\hline & Azotobacter & 0.16 & 0.18 & 0.17 & 2.560 & 2.963 & 3.110 \\
\hline & Azospirllum & 0.13 & 0.16 & 0.15 & 2.540 & 2.887 & 2.933 \\
\hline & Mixed & 0.17 & 0.19 & 0.18 & 2.670 & 3.060 & 3.240 \\
\hline \multirow{4}{*}{4000} & Control & 0.03 & 0.05 & 0.04 & 1.173 & 1.877 & 2.007 \\
\hline & Azotobacter & 0.14 & 0.17 & 0.15 & 2.290 & 2.837 & 3.030 \\
\hline & Azospirllum & 0.13 & 0.15 & 0.13 & 2.120 & 2.757 & 2.820 \\
\hline & Mixed & 0.16 & 0.17 & 0.17 & 2.587 & 2.953 & 3.157 \\
\hline \multicolumn{8}{|c|}{ L.S.D. at $5 \%$ for } \\
\hline & Salinity & 0.01 & 0.02 & 0.01 & 0.02 & 0.02 & 0.66 \\
\hline & Biofertilizer & 0.01 & 0.01 & 0.01 & 0.04 & 0.04 & 0.50 \\
\hline & Interaction & 0.01 & N.S & 0.01 & 0.06 & 0.06 & N.S \\
\hline
\end{tabular}


Data presented in Tables ( 8 and 9) clearly indicated that increasing salinity irrigation water up to $4000 \mathrm{\mu gl}^{-1}$ significantly decreased plant height, number of branches per plant, fresh and dry weight / plant of safflower plant after 35, 70 and 120 days from sowing in the first and second seasons compared with $2000 \mathrm{gI}^{-}$ ${ }^{1}$. The gradual depression occurred in all the growth characters of safflower plant due to the irrigation with saline water. Thus, as salinity is a condition of excess salts in soil solution, it affects plant by increasing the osmotic pressure of the soil solution. These results are in agreement with those obtained by Ebrahim et al. (2010), Mostafavi (2011) and Aymen et al. (2012). They found that increasing salinity in irrigation water decreased growth characters of safflower plant.

The interaction between biofertilizer and irrigation water salinity had a significant effect on growth characters of safflower plants at all sampling dates in the second season (Tables, 8 and 9). The highest value of growth characters of safflower plants were recorded when irrigated by $2000 \mathrm{mgl}^{-1}$ and inoculated with mixed Azotobacter and Azospirillum at all sampling in both seasons, Kaci et al., (2005) reported that, Azospirillum and Azotobacter are known to deliver a number of benefits including plant nutrition, disease resistance, and tolerance to adverse soil and climatic conditions. Their function ranges from stress alleviation to soil bioremediation or as a biological tool for sustainable agriculture.

Interaction between biofertilizers and water irrigation salinity on yield and its components of safflower

The results summarized in Tables (10) show that biofertilizer treatments had positive significant effects on number of heads /plant, head diameter, number of seeds / head, weight of 100 seed, seed yield $(\mathrm{Kg} / \mathrm{fed})$ and stand \% during the two seasons compared with uninoculated plants.

Mixed inoculations with Azotobacter and Azospirillum gave the highest values of yield and its components and survival plant of safflower as compared with the control treatment. The positive response of yield as a result of inoculation with Azotobacter and Azospirillum may be due to the high ability of these microbes in $\mathrm{N}_{2}$-fixation and the secretion of several compounds that increase soil fertility and decomposition of organic materials that increase the plant's ability to grow and increase productivity. Seed yield and yield components of safflower have been significantly affected by the inoculation with Azotobacter and Azospirillum, because these biofertilizers can fix atmospheric nitrogen, increase phosphorus availability in soil and enhanced absorb elements by safflower plant (Mirzakhani et al., 2009, Mohammad et al. 2010, Mahmoud et al., 2012, Omid and Jalilian, 2012, Raouf, 2012, Mina et al., 2013 and Paritosh et al., 2013). The depression effect of salinity on plants may not show water deficit symptoms and metabolize normally under the applied salinity levels, the additional energy requirements for maintaining normal metabolism demand substantial photosynthetic diversions for growth. This leads to a reduction in yield, light interception and light utilization efficiency which attributed to partial stomata closure and simultaneously decrease in $\mathrm{Co}_{2}$ fixation that ultimately reduce growth and yield (Aymen et al. 2012, Neeta 2012 and Mostafavi, 2011). 
J. Soil Sci. and Agric. Eng., Mansoura Univ., Vol. 4 (8), August, 2013 8-9 
Data presented in Table (10) show that the interaction between salinity and biofertilizer had a significant effect on head diameter, number of seeds / head, weight of 100 seed. The highest value of yield characters of safflower plant were recorded with irrigated by $2000 \mathrm{\mu gl}^{-1}$ and inoculated with coinoculation.

In general it can be said that the use of biofertilizers with safflower plant at all levels of salinity of irrigation water gave positive results as compared to the control. This is due to the high ability of these microbes in $\mathrm{N}_{2}$-fixating atmosphere and the secretion of several compounds that increase soil fertility and decomposition of organic materials that increase the plant's ability to grow and increase productivity under those levels of salinity of irrigation water. In addition, Abou-Aly et al. (2012) reported that application of biofertilizers as bio stimulate for pepper grown in saline soil can improve plant defense against saline stress conditions, increase productivity and enhanced plant defense to stress through the decreasing of proline accumulation and increasing of some compounds as an indicator to plant resistance for saline stress.

\section{Interaction effect of biofertilizer and water irrigation salinity on chemical} composition of safflower

Results in Table (10) revealed that biofertilizer treatments had a significant effect on protein, phosphorus, oil percentage and oil yield at harvest. The highest value of chemical composition was obtained by using dual inoculation with Azotobacter and Azospirillum. These results confirmed by the work of Omid and Jalilian. (2012), Mina et al. (2013) and Paritosh et al. (2013).

Results also show that increasing salinity in irrigation water significantly decreased chemical composition of safflower plants. Increasing salinity from 2000 to $4000 \mathrm{mgl}^{-1}$ decreased protein, phosphorus, oil percentage and oil yield. Such reduction in protein content may be due to failure of plants to make full utilization of nitrogen compounds, the accumulation of nitrogen compounds is more rapid than their utilization in building more cells and organs. These results are in agreement with those obtained by Siddiqee (2010).

The interaction between salinity and biofertilizer had a significant effect on protein, oil percentage and oil yield of safflower. The highest value of protein, phosphorus, oil percentage and oil yield was obtained by plants irrigated $2000 \mathrm{gl}^{-1}$ and inoculated with both biofertilizers. 
J. Soil Sci. and Agric. Eng., Mansoura Univ., Vol. 4 (8), August, 2013 10 


\section{Conclusion}

From the obtained results it can be said that, application of dual inoculation with $A$. chroococcum and Azospirllum lipoferum. or individually improve plant growth and increase productivity due to the ability of these microbes to do many of the tasks next to its ability to fix high amount of nitrogen, secretion of several hormones and thawed several of soil elements needed by the plant during the period of growth and can tolerate high levels of salinity of irrigation water used. Also, reduced the economically production and the hazard of the doses of mineral fertilizers.

\section{REFERENCES}

A.O.C.S. (1964). Official and tentative methods of American Oil Chemists Society. 2nd Ed. Published by the American Oil Chemists. Society, 35, East Wacker Drive, Chicago Illinois, U.S.A., pp. $16-18$.

Abd El-Gawad, A.M. (1998). Effect of some soil microorganisms on the fertility of Egyptian desert soil. M.Sc. Thesis, Fac. of Science, Ain Shams Univ., Cairo, Egypt.

Abd El-Gawad, A.M. (2008). Study the induction effect of Azospirillum inoculation on the formation of para-nodules on gramineae. Annals Agric. Sci., Ain Shams Univ., 53(1).91-103

Abd El-Ghany, Bouthaina. F. (1996). Influence of different bacterial strains as biofertilizers on wheat crop production in new cultivated land. Desert. Lnst. Bull., Egypt. 47(1): 69-100.

Abd El-Malek, Y. and Y.Z. Ishac (1968). Evaluation of methods used in counting Azotobacter. J. APPL Bacteriol., 31: 267-275.

Abou-Aly, H. E.; R. A. zaghloul; Ehsan, A. Hanfy, A. GH. Rahal and Rasha, M. EL-Meihy (2012). Colonization of pepper roots with salt-tolerant PGPR as inducer for saline stress. The eleventh conference of agricultural development researches, 27-30 March, 2012. Fac. Agric, Ain Shams Univ., Egypt.

Aymen, E. M., K. Zhani, F. Meriem Ben and C. Hannachi. (2012). Seed priming for better growth and yield of safflower (Carthamus tinctorius) under saline condition. Journal of Stress Physiology \& Biochemistry, 8 (3): $\mathrm{p} 125$.

Bergey's Manual of Systematic Bacteriology (1984). Gram positive Bacillus. V01. 1, Section 4, cited from Krieg N.R. and J.G. Holt (Eds.), p. $220-$ 229, Williams and Wilkins, Baltimore, USA.

Black, C. A. (Ed.) (1965). Methods of soil analysis. Part 1 and 2 Amer. Soc. Of Agron Inc., Pub. Madison, Wisconison, U.S.A.

Bremner, J.M.: Total nitrogen. In: Methods of soil analysis. Part 2, Chemical and microbiological properties (Eds.: C.A. Black, D.D. Evans, J.L. White, L.E. Ensminger and F.E. Clark). Agronomy 9. ASA, Madison, Wisconsin. pp. 1149-1176 (1965).

Bunt, J.S. and A.O. Rovira (1955). Microbiological studied of some subontoretic soil. Journal of Soil Science, 6: 119-126. 
Dobereiner, J. (1978): Influence of environmental factors on the occurrence of $S$. lipoferum in soil and roots. Ecol. Bull. (Stockholm) 26:343-352.

Ebrahim, N., G. Mohammadi-Nejad, K. Yousefi and H. Farahbakhsh. (2010). Evaluation salinity tolerance of safflower (Carthamus tinctorius L.) Genotypes at different vegetative growth stages. Intl. J. Agron. Plant. Prod. 1 (4): 105-111.

El-Sayed, M.A.M. (2006). Effect of biofertilizers application on the productivity of Nigella saliva cultivated in desert sandy soils and efficiency of produced seeds against some pathogenic microorganisms. Ph.D. Thesis, Fac. Agric., Moshtohor, Benha Univ., Egypt.

EL-Tayeb, M. A. A. M. (2000). Physiological studies on halotolerant Azosoirillum in improving cereals productivity under desert soil conditions Ph. D. Thesis, Fac. Agric., Ain Shams Univ., Cairo, Egypt.

Faid, E.M.Y.A (2000). Physiological studies on halotolerant Azotobacter in Desert soil. Ph. D. Thesis, Fac. Agric., Ain Shams Univ., Cairo, Egypt.

Frie, E., K. Peyer and E. Schutz (1964). Determination of phosphorus by ascorbic acid. Schw Landaiir- Tech Forschung. Heft., $3: 318-328$.

Hashem A. Farh and Bouthaina. F. Abd El-Ghany (1992). Nitrogen balance in saline calcareous soil of Wadi Sudr under wheat production. Desert Inst. Bull., Egypt, 42 (1): 107 - 117.

Jackson, M.L. (1967). Soil chemical analysis. Prin. Hall, India, Private, New Delhi.

Kaci, Y., A. Heyraud, B. Mohamed and T. Heulin, 2005. Isolation and identification of an EPS-producing Rhizobium strain from arid soil (Algeria): characterization of its EPS and the effect of inoculation on wheat rhizosphere soil structure. Research in Microbiology, 156(4): 522- 531.

Khalifa, Neamat, A.M. (2005). The application of biofertilization and biological control for tomato production. Ph.D Thesis, Fac. Agric., Moshtohor, Zagazig University

Mahmoud, G., M.S. Moghaddasi and A.H. Omidib (2012). The Effects of biological and chemical nitrogen fertilizers on agronomical traits of winter safflower cultivars in Saveh region of Iran. Annals of Biological Research, 3 (11):5141-5144

Mina, P., A. Ayenehband and A. Modhej. (2013). The effect of biological and chemical fertilizers and plant density onquality and quantity yield of Safflower (Carthamus tinctorius.L) underAhvaz condition. International journal of Agronomy and Plant Production. 4 (3): 524-529.

Mirzakhani, M., M.R. Ardakani, A. Aeene Band, F. Rejali and A.H. Shirani Rad. (2009). Response of Spring Safflower to Co-Inoculation with Azotobacter chroococumand Glomus intraradices Under Different Levels of Nitrogen and Phosphorus. Directory of Open Access Journals.(10): 255-261. 
Mohammad, F., A.H. Mohammad and M Behrouz (2010) Saline irrigation water management strategies for better yield of safflower (Carthamus tinctorius L.) in an arid region. Australian Journal of Crop Science, 4(6):408-414

Mostafavi, K. (2011). An evaluation of safflower genotypes (Carthamus tinctorius L.), seed germination and seedling characters in salt stress conditions. African Journal of Agricultural Research. 6(7): 1667-1672.

Muhammad, J., S. Rehman and E.S. Rha1 (2007). Salinity effect on plant growth, psii photochemistry and chlorophyll content sugar beet (Beta vulgaris L.) and cabbage (Brassica oleracea capitata L.). Pak. J. Bot., 39(3): 753-760.

Neeta, M.P. (2012). Adaptations in response to salinity in safflower Cv. Bhima. Asian Journal of Crop Science, 4: 50-62.

Omid, M. and J. Jalilian. (2012). Response of safflower seed quality characteristics to different soil fertility systems and irrigation disruption. International Research Journal of Applied and Basic Sciences, 3 (5): 968-976.

Paritosh, P., B.K. Pati, G.K. Ghosh, S. S. Mura and A. Saha. (2013). Effect of biofertilizers and sulphur on growth, yield, and oil content of hybrid sunflower (Helianthus annuus. L) In a typical lateritic soil. Open Access Scientific Reports,2 (1):1-5.

Peach, K. and M. V. Tracey (1956). Modern methods of combination of pig slurry and mineral nitrogen fertilizer. J. Agric. Sci. Camb., 127: 151 159.

Pramer, D. and E.L. Schmidt (1964). Experimental soil microbiology. Burgess Publ. Co., Minnesota, USA.

Rahim, N. and A. Mirzaei (2010) Response of yield and yield components of Safflower (Carthamus tinctorius L.) to seed inoculation with Azotobacte and Azospirillum and different nitrogen levels under dry land conditions. American - Eurasian J. Agric. \& Environ. Sci., 9(4): 445 449.

Raouf, S.S. (2012). Effects of nitrogen rates and seed inoculation with plant growth promoting rhizobacteria (PGPR) on grain yield and some growth indices in Safflower (Carthamus tinctories L.) International Journal of Agriculture and Crop Sciences, 4 (14): 949-954.

Richards, S. (1954). Diagnosis and improvement of saline and alkaline soil. Agric. Hand book. U.S.A. (60).

Rumasz, E.; Z. Koszanski, R. Biczak and P. Rychter. (2002). Influence of saline water irrigation on the yield and some physiological processes of red beet. Folia Universitatis Agriculturae Stetinensis Agricultura., 90: 207-212.

Siddiqee, A.H. (2010). Influence of salt stress on some physiological and biochemical attributes, and oil composition of a potential oilseed crop safflower (Carthamus tinctorius L.). Ph.D. Thesis, University of Agriculture, Faisalabad

Snedecor, G. W. and W. G. Cochran. (1989). Statistical methods, $8^{\text {th }}$ Ed., lowa state Univ., press, lowa, U. S. A. 
Steel, G.D.R. (1960). Principles and procedures of statistics. New York McGraw-Hill Book Co., pp. 481.

Thalmann, A. (1967). Uber die microbiello Akivitat undihr Beziehung Zu fruchtbartkeits merkmalen eini-ger Acherboden unter besonderer Berucksi chtigung der dehydrogenase akativitat (TTC. Redukation). Biss Gieben PH.D.Thesis.W. Germany.

Tripath, R.D. G.P. Srivastava, M.S. Misra, and S.C. Pandey (1971). Protein content in some variations of legumes. The Allah Abad former. 16: 291-294.

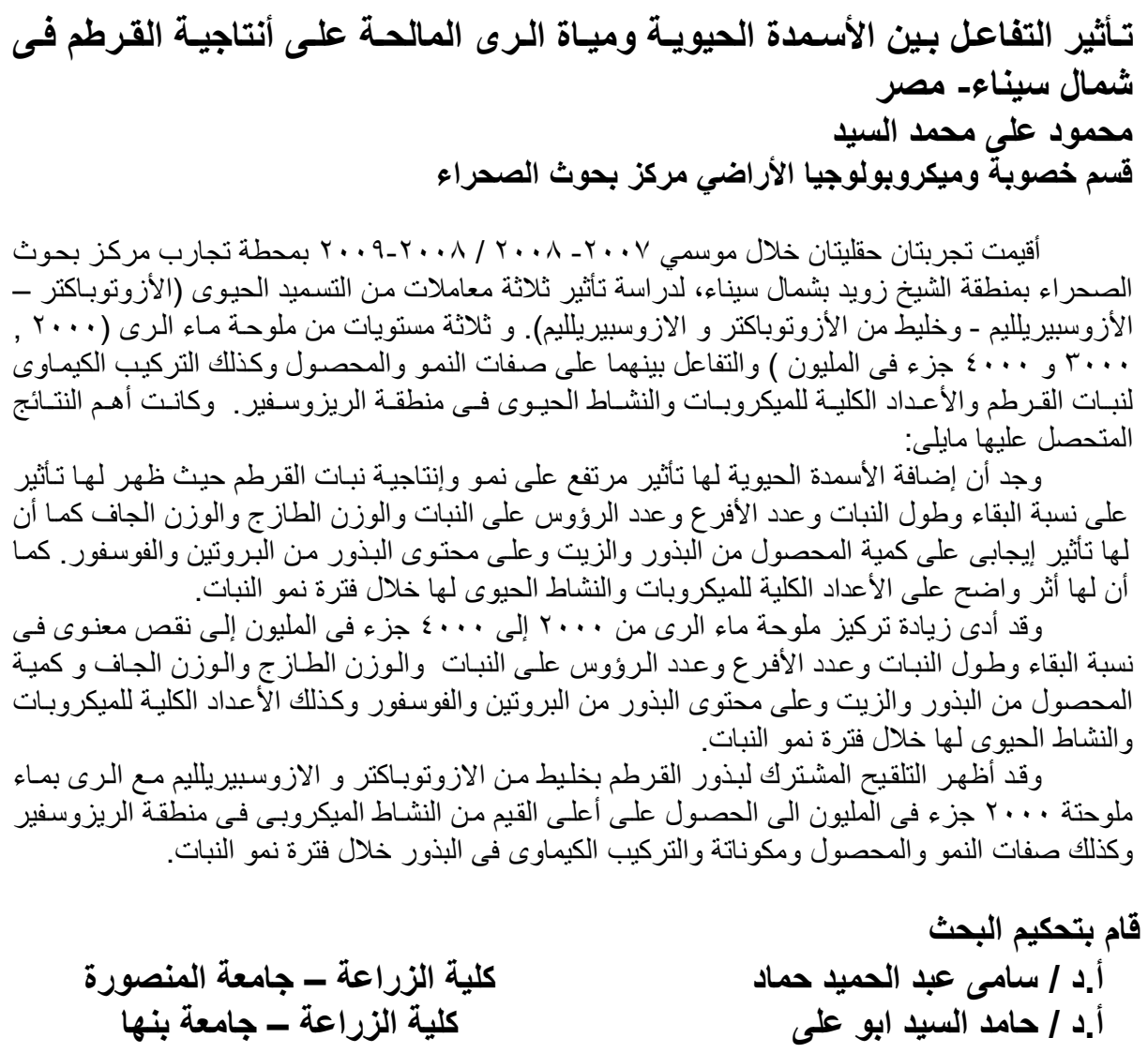


El-Sayed, M. A. M. 
Table (8) Effect of interaction between biofertilization and saline irrigation on plant height and number of branches/plant of Safflower during 2007/2008 and 2008/2009 seasons.

\begin{tabular}{|c|c|c|c|c|c|c|c|c|c|c|c|c|c|}
\hline \multirow{4}{*}{\multicolumn{2}{|c|}{ Irrigation Inoculation }} & \multicolumn{6}{|c|}{ Plant height $(\mathrm{cm})$} & \multicolumn{6}{|c|}{ Number of branches/plant } \\
\hline & & \multirow{2}{*}{\multicolumn{3}{|c|}{$\begin{array}{c}\text { First season } \\
\text { Days after sowing }\end{array}$}} & \multirow{2}{*}{\multicolumn{3}{|c|}{$\begin{array}{l}\text { Second season } \\
\text { Days after sowing }\end{array}$}} & \multirow{2}{*}{\multicolumn{3}{|c|}{$\begin{array}{c}\text { First season } \\
\text { Days after sowing }\end{array}$}} & \multirow{2}{*}{\multicolumn{3}{|c|}{$\begin{array}{l}\text { Second season } \\
\text { Days after sowing }\end{array}$}} \\
\hline & & & & & & & & & & & & & \\
\hline & & 35 & 70 & 120 & 35 & 70 & 120 & 35 & 70 & 120 & 35 & 70 & 120 \\
\hline & Control & 33.3 & 81.9 & 114.3 & 30.3 & 115.8 & 132.2 & 5.2 & 7.1 & 9.2 & 4.8 & 8.1 & 10.2 \\
\hline & Azotobacter & 36.8 & 171.6 & 174.7 & 42.7 & 176.2 & 176.9 & 6.8 & 12.3 & 15.4 & 8.3 & 12.7 & 16.8 \\
\hline $2000 \mu \mathrm{g}$ & Azospirllum & 35.7 & 162.3 & 170.4 & 42.2 & 165.8 & 173.4 & 6.4 & 11.4 & 13.1 & 6.1 & 12.1 & 14.7 \\
\hline & Mixed & 41.2 & 177.4 & 182.4 & 44.4 & 187.3 & 184.3 & 9.1 & 18.7 & 20.9 & 10.9 & 20.8 & 23.3 \\
\hline & Control & 30.4 & 77.2 & 110.4 & 27.3 & 115.3 & 125.1 & 4.4 & 5.9 & 6.8 & 4.4 & 7.2 & 9.2 \\
\hline & Azotobacter & 35.2 & 154.7 & 160.7 & 38.9 & 146.7 & 160.4 & 6.2 & 11.2 & 14.2 & 7.3 & 12.1 & 15.9 \\
\hline $\mathrm{J} \mu \mathrm{gl}$ & Azospirllum & 33.7 & 142.4 & 149.3 & 36.7 & 145.4 & 151.3 & 5.3 & 8.7 & 11.7 & 5.2 & 10.3 & 14.3 \\
\hline & Mixed & 38.4 & 162.3 & 172.8 & 41.4 & 170.1 & 174.4 & 7.1 & 15.3 & 18.3 & 8.1 & 16.8 & 20.8 \\
\hline & Control & 27.2 & 72.3 & 100.4 & 23.1 & 100.2 & 120.3 & 2.3 & 4.3 & 5.3 & 3.4 & 6.4 & 7.3 \\
\hline & Azotobacter & 31.6 & 146.8 & 155.9 & 38.3 & 150.4 & 160.2 & 4.4 & 9.1 & 11.2 & 5.2 & 9.3 & 12.7 \\
\hline $4000 \mu \mathrm{gl}$ & Azospirllum & 30.3 & 135.4 & 142.2 & 33.8 & 137.9 & 153.1 & 3.2 & 7.4 & 8.9 & 4.3 & 8.2 & 12.2 \\
\hline & Mixed & 36.4 & 153.9 & 168.7 & 39.2 & 156.6 & 170.9 & 5.1 & 11.8 & 14.3 & 6.4 & 13.4 & 17.8 \\
\hline L.S.D. at & $5 \%$ for & & & & & & & & & & & & \\
\hline & Salinity & 0.33 & 19.64 & 9.16 & 0.19 & 8.66 & 9.82 & 1.10 & 0.29 & 0.32 & 0.57 & 2.01 & 0.29 \\
\hline & Biofertilizer & 0.29 & 8.61 & 5.22 & 0.17 & 4.04 & 2.86 & 0.42 & 0.48 & 0.40 & 0.51 & 0.45 & 0.38 \\
\hline & Interaction & 0.50 & N.S & N.S & 0.29 & 3.83 & 4.95 & N.S & 0.83 & 0.69 & 0.89 & 1.11 & 0.65 \\
\hline
\end{tabular}

Table (9) Effect of interaction between biofertilization and saline irrigation on fresh and dry weight/plant of Safflower during 2007/2008 and 2008/2009 seasons.

\begin{tabular}{|c|c|c|c|c|c|c|c|c|c|c|c|c|c|}
\hline \multirow{4}{*}{ Irrigation } & \multirow{4}{*}{ Inoculation } & \multicolumn{6}{|c|}{ Fresh weight } & \multicolumn{6}{|c|}{ Dray weight } \\
\hline & & \multicolumn{3}{|c|}{ First season } & \multirow{2}{*}{\multicolumn{3}{|c|}{$\begin{array}{l}\text { Second season } \\
\text { owing }\end{array}$}} & \multicolumn{3}{|c|}{ First season } & \multicolumn{3}{|c|}{ Second season } \\
\hline & & & & ays aft & & & & & & ays aft & owing & & \\
\hline & & 35 & 70 & 120 & 35 & 70 & 120 & 35 & 70 & 120 & 35 & 70 & 120 \\
\hline \multirow{4}{*}{$2000 \mu \mathrm{gl}^{-1}$} & Control & 107.2 & 249.7 & 300.2 & 92.3 & 270.2 & 311.9 & 9.7 & 19 & 14.9 & 8.9 & 21.5 & 15.8 \\
\hline & Azotobacter & 260.4 & 550.3 & 590.4 & 280.1 & 546.8 & 615.2 & 17.7 & 57.4 & 56.0 & 19.2 & 58.1 & 59.2 \\
\hline & Azospirllum & 230.3 & 370.1 & 4102 & 254.6 & 432.4 & 511.7 & 15.7 & 54.3 & 47.1 & 17.6 & 56.2 & 59.9 \\
\hline & Mixed & 284.6 & 574.9 & 601.7 & 337.8 & 600.3 & 670.4 & 21.2 & 59.1 & 63.3 & 27.1 & 65.4 & 71.5 \\
\hline \multirow{4}{*}{$3000 \mu \mathrm{gl}^{-1}$} & Control & 184.7 & 205.8 & 284.6 & 220.7 & 250.2 & 304.7 & 6.7 & 13.2 & 13.0 & 6.4 & 19.1 & 24.6 \\
\hline & Azotobacter & 205.2 & 245.2 & 384.9 & 237.6 & 422.4 & 500.3 & 12.3 & 36.8 & 33.6 & 14.8 & 47.9 & 45.6 \\
\hline & Azospirllum & 204.6 & 284.6 & 375.3 & 236.3 & 364.1 & 410.2 & 11.5 & 34.3 & 32.7 & 13.2 & 43.6 & 42.8 \\
\hline & Mixed & 250.4 & 490.3 & 520.1 & 287.4 & 504.8 & 561.6 & 15.7 & 41.4 & 44.1 & 28.2 & 51.1 & 57.7 \\
\hline \multirow{4}{*}{$4000 \mu \mathrm{gl}^{-1}$} & Control & 90.3 & 150.2 & 203.7 & 185.9 & 214.6 & 284.8 & 2.9 & 12.8 & 13.0 & 5.9 & 17.4 & 20.2 \\
\hline & Azotobacter & 110.1 & 270.4 & 304.9 & 205.6 & 400.3 & 440.2 & 12.9 & 28.5 & 23.6 & 14.2 & 34.3 & 40.1 \\
\hline & Azospirllum & 114.8 & 217.7 & 300.3 & 166.7 & 310.1 & 370.1 & 9.6 & 23.4 & 22.8 & 12.9 & 33.3 & 38.1 \\
\hline & Mixed & 190.3 & 264.9 & 351.6 & 230.8 & 415.7 & 460.4 & 13.3 & 37.4 & 31.9 & 16.2 & 43.1 & 51.7 \\
\hline \multicolumn{2}{|c|}{ L.S.D. at $5 \%$ for } & & & & & & & & & & & & \\
\hline & Salinity & 10.47 & 4.79 & 5.97 & 3.11 & 18.89 & 4.39 & 0.38 & 0.44 & 0.42 & 1.07 & 1.89 & 5.00 \\
\hline & Biofertilizer & 5.59 & 4.36 & 4.37 & 4.05 & 16.51 & 7.57 & 0.33 & 0.80 & 0.99 & 0.58 & 1.65 & 3.89 \\
\hline & Interaction & 9.69 & 7.54 & 7.56 & 7.01 & 28.58 & 13.10 & 0.57 & 1.58 & 2.41 & 1.00 & 2.86 & 6.74 \\
\hline
\end{tabular}




\section{El-Sayed, M. A. M.}

Table (10) Effect of interaction between biofertilization and saline irrigation on yield components and chemical contents of Safflower at harvest Yield and its components

\begin{tabular}{|c|c|c|c|c|c|c|c|c|c|c|c|}
\hline \multirow[b]{3}{*}{ Irrigation } & \multicolumn{11}{|c|}{ First season } \\
\hline & \multirow[b]{2}{*}{ Inoculation } & \multicolumn{6}{|c|}{ Yield and its components } & \multicolumn{4}{|c|}{ Chemical contents } \\
\hline & & $\begin{array}{l}\text { No. of } \\
\text { heads } \\
\text { /plant }\end{array}$ & $\begin{array}{c}\text { Diameter of } \\
\text { head }(\mathrm{cm})\end{array}$ & $\begin{array}{l}\text { No. of } \\
\text { seeds } \\
\text { /head }\end{array}$ & \begin{tabular}{|c} 
Weight of \\
100 \\
seed $(\mathrm{g})$ \\
\end{tabular} & $\begin{array}{c}\text { Seed yield } \\
\mathrm{Kg} \mathrm{fed}^{-1}\end{array}$ & Stand \% & $\begin{array}{c}\text { Protein } \\
(\%)\end{array}$ & $\begin{array}{c}\text { Phosphorus } \\
(\%)\end{array}$ & $\begin{array}{l}\text { Oil } \\
(\%)\end{array}$ & $\begin{array}{c}\text { Oil yield } \\
\mathbf{k g} / \mathrm{fed}\end{array}$ \\
\hline \multirow{4}{*}{$2000 \mathrm{Hgl}^{-1}$} & Control & 6.9 & 2.50 & 32.48 & 3.02 & 405.05 & 19.4 & 5.25 & 0.27 & 27.15 & 117.43 \\
\hline & Azotobacter & 14.0 & 3.04 & 48.28 & 3.72 & 715.69 & 20.4 & 8.29 & 0.34 & 32.18 & 248.43 \\
\hline & Azospirllum & 11.8 & 2.99 & 47.08 & 3.55 & 680.00 & 19.4 & 7.21 & 0.33 & 30.69 & 225.53 \\
\hline & Mixed & 19.7 & 3.25 & 51.18 & 4.08 & 726.52 & 21.6 & 10.03 & 0.35 & 38.41 & 297.99 \\
\hline \multirow{4}{*}{3000} & Control & 5.6 & 2.43 & 28.48 & 2.48 & 383.76 & 15.9 & 4.68 & 0.23 & 21.44 & 104.23 \\
\hline & Azotobacter & 12.5 & 2.53 & 32.53 & 3.26 & 520.35 & 18.2 & 6.97 & 0.31 & 25.87 & 166.93 \\
\hline & Azospirllum & 10.7 & 2.43 & 32.43 & 3.21 & 507.95 & 17.3 & 6.92 & 0.30 & 23.86 & 152.43 \\
\hline & Mixed & 18.0 & 2.78 & 45.75 & 3.44 & 587.85 & 20.0 & 7.10 & 0.32 & 30.11 & 214.53 \\
\hline \multirow{4}{*}{$4000 \mathrm{Hgl}^{-}$} & Control & 3.8 & 2.37 & 27.13 & 1.84 & 372.90 & 8.4 & 3.92 & 0.19 & 17.71 & 90.73 \\
\hline & Azotobacter & 9.4 & 2.43 & 29.72 & 3.08 & 467.35 & 15.5 & 6.73 & 0.27 & 23.74 & 143.97 \\
\hline & Azospirllum & 8.5 & 2.39 & 27.80 & 3.05 & 428.76 & 12.6 & 6.08 & 0.25 & 20.86 & 119.03 \\
\hline & Mixed & 14.9 & 2.48 & 31.37 & 3.19 & 488.45 & 16.4 & 6.97 & 0.30 & 25.01 & 157.03 \\
\hline \multicolumn{12}{|c|}{ L.S.D. at $5 \%$ for } \\
\hline & Salinity & 0.851 & 0.159 & 0.717 & 0.159 & 0.319 & 1.328 & 1.461 & 0.027 & 0.053 & 2.018 \\
\hline & Biofertilizer & 1.009 & 0.186 & 1.169 & 0.186 & 0.398 & 1.514 & 2.470 & 0.053 & 0.053 & 2.311 \\
\hline & Interaction & 0.271 & 0.009 & 0.197 & 0.009 & 0.042 & 0.664 & 0.807 & N.S & 7.967 & 1.548 \\
\hline \multicolumn{12}{|c|}{ Second season } \\
\hline & Control & 10.5 & 3.10 & 39.08 & 7.22 & 419.65 & 28.2 & 9.4 & 0.45 & 37.79 & 133.87 \\
\hline 2000 & Azotobacter & 17.6 & 3.64 & 54.88 & 7.92 & 730.29 & 35.0 & 12.4 & 0.52 & 42.82 & 264.87 \\
\hline \multirow{3}{*}{$\mu g^{-1}$} & Azospirllum & 15.4 & 3.59 & 53.68 & 7.75 & 694.60 & 34.0 & 11.4 & 0.51 & 41.33 & 241.97 \\
\hline & Mixed & 23.3 & 3.85 & 57.78 & 8.28 & 741.12 & 36.2 & 14.2 & 0.53 & 49.05 & 314.43 \\
\hline & Control & 9.2 & 3.03 & 35.08 & 6.68 & 398.36 & 30.5 & 8.8 & 0.41 & 32.08 & 120.67 \\
\hline 3000 & Azotobacter & 16.1 & 3.13 & 39.13 & 7.46 & 534.95 & 32.8 & 11.1 & 0.49 & 36.51 & 183.37 \\
\hline \multirow{2}{*}{$\mu \mathrm{gl}^{-1}$} & Azospirllum & 14.3 & 3.03 & 39.03 & 7.41 & 522.55 & 31.9 & 11.1 & 0.48 & 34.50 & 168.87 \\
\hline & Mixed & 21.6 & 3.38 & 52.35 & 7.64 & 602.45 & 34.6 & 11.2 & 0.50 & 40.75 & 230.97 \\
\hline & Control & 7.4 & 2.97 & 33.73 & 6.04 & 387.5 & 23.0 & 8.1 & 0.37 & 28.35 & 107.17 \\
\hline & Azotobacter & 13.0 & 3.03 & 36.32 & 7.28 & 481.95 & 30.1 & 10.9 & 0.45 & 34.38 & 160.41 \\
\hline \multirow[t]{2}{*}{$\mu \mathrm{gl}^{-1}$} & Azospirllum & 12.1 & 2.99 & 34.40 & 7.25 & 443.36 & 27.2 & 10.2 & 0.43 & 31.50 & 135.47 \\
\hline & Mixed & 18.5 & 3.08 & 37.97 & 7.39 & 503.05 & 31.0 & 11.1 & 0.48 & 35.65 & 173.47 \\
\hline \multicolumn{12}{|c|}{ L.S.D. at $5 \%$ for } \\
\hline & Salinity & 1.062 & 0.159 & 0.876 & 0.053 & 0.133 & 1.514 & 0.345 & 0.053 & 0.451 & 15.19 \\
\hline & Biofertilizer & 1.169 & 0.186 & 1.169 & 0.053 & 0.159 & 1.726 & 0.478 & 0.053 & 0.505 & 17.37 \\
\hline & Interaction & 0.451 & 0.009 & 0.295 & 6.108 & 0.007 & 0.886 & 0.045 & N.S & 0.074 & 88.53 \\
\hline
\end{tabular}

